\title{
Compatibility of Copper hydroxide (Kocide 3000) with Biocontrol Agents
}

\author{
Pandian Valarmathi, Sushil Kumar Pareek, Vanaraj Priya, Ramalingam \\ Rabindran and Gopal Chandrasekar \\ Department of Plant Pathology, Centre for Plant Protection Studies, Tamil Nadu Agricultural University, \\ Coimbatore - 641003, India
}

\begin{abstract}
An experiment was conducted to study the compatibility of copper hydroxide (Kocide 3000) with bacterial and fungal biocontrol agents under in vitro conditions. Bacterial biocontrol agents viz., Pseudomonas fluorescens and Bacillus subtilis were compatible with copper hydroxide (Kocide 3000) even at a high concentration of 300 ppm. Fungal biocontrol agent, Trichoderma viride was inhibited by copper hydroxide at a concentration above 2500 ppm. The fungal biocontrol agent was highly compatible with the fungicide than the bacterial biocontrol agents.
\end{abstract}

Key words: Copper hydroxide (Kocide 3000), Pseudomonas fluorescens, Bacillus subtilis, Trichoderma viride

\section{Introduction}

Kocide 3000 manufactured by DuPont, a copper based fungicide/bactericide was reported to inhibit wide range of fungal and bacterial pathogens. The active ingredient is copper hydroxide ( 35 per cent) with 30 per cent metallic copper equivalent. It was used for the management of wide range of fungal and bacterial diseases in various crops viz., in citrus against Phytophthora foot rot and canker; in almond and apricot against Pseudomonas; in apple against scab and anthracnose; in banana against sigatoka leaf spot; in grapes against downy mildew and black rot; in coffee against bacterial blight caused by Pseudomonas syringae; in peach against bacterial canker and bacterial spot (caused by Xanthomonas spp), in tomato against bacterial speck. (http://www.dupont.com/ProductionAgriculture/en_US/products_services/fungicides/Kocide3000_fungicide.ht $\mathrm{ml}-25 \mathrm{k})[1]$

Since fungicides may have deleterious effects on the pathogen as well as the antagonist, an understanding of the effect of fungicides on the pathogen and the antagonist, would provide an information on the selection of selective fungicides and fungicide resistant antagonists. The idea of combining biocontrol agents (BCA) with fungicides is for the development or establishment of desired microbes in the rhizosphere (Papavizas and Lewis, 1981 [2]). Further, the antagonism of BCA was influenced by the addition of fungicides (Kay and Stewart, 1994 [3]; Naar and Kecskes, 1999 [4]). Many authors reported the compatibility of fungicides with biocontrol agents in various crops (Utkhede and Koch, 2002 [5]; Senthilvel et al., 2004 [6]; Anand et al., 2007 [7]).

The indiscriminative use of potentially hazardous fungicides poses a serious threat to environment. The compatibility on beneficial organisms such as nitrogen fixers, residential antagonists and mycorrhizal fungi are the other advantages of the application of fungicides (Rodriguez- kabana and Curl, 1980 [8]). Singh et al., 1995 [9] reported that selected isolates of T. harzianum, T. viride, T. reesei and T. koningi were tested with Captaf ${ }^{\circledR}$ 500 ppm, Dithane M- 45 ${ }^{\circledR} @ 500$ ppm and Thiram @ 200ppm. The fungicides were highly inhibitory to $T$. reesei and they were compatible to T. koningi. Thiram at $200 \mathrm{ppm}$ inhibited T. viride while the rest of the two fungicides were compatible with T. viride. Dubey, H. C., 2000 [10] recommended the combined use of fungicides and bio control agents for the management of web blight caused by $R$. solani in groundnut. The combination of biological control agents with fungicides would provide similar disease supression as achieved with higher fungicide use. With this literature as background, studies were carried out to find the compatibility of copper hydroxide with bacterial and fungal biocontrol agents.

\section{Materials and methods}

The bacterial biocontrol agent, Pseudomonas fluorescens Migula (Pf 1) and Bacillus subtilis (SVPR4) and fungal biocontrol agents Trichoderma viride (TV1) were obtained from Department of Plant Pathology, Tamil Nadu Agricultural University, Coimbatore. Copper hydroxide (Kocide 3000) was purchased from the Du Pont regional manager.

\subsection{Compatibility of Copper hydroxide (Kocide 3000) with biocontrol agents}

\subsubsection{Turbidometric method}

One $\mathrm{ml}$ of the each bacterial culture viz., P. fluorescens and B. subtilis was transferred to a $250 \mathrm{ml}$ sidearm flask containing $50 \mathrm{ml}$ of King's B and Nutrient Agar broth, respectively and amended with Copper 
hydroxide (Kocide 3000) technical standard at five different concentrations viz., 100, 200, 300, 400 and 500 ppm. The control was maintained without inoculation of bacterial culture and copper hydroxide (Kocide 3000) technical standard in both. The flasks were incubated at $28 \pm 1{ }^{\circ} \mathrm{C}$ in a psychotherm shaker. The optical density values of the culture broth were determined in Spectrophotocolorimeter at $610 \mathrm{~nm}$ at regular intervals of $6 \mathrm{~h}$.

\subsubsection{Poisoned food technique}

The compatibility of Trichoderma viride with copper hydroxide (Kocide 3000) was tested. Potato dextrose agar (PDA) was used as the basal medium to which calculated quantities of copper hydroxide (Kocide 3000) was separately mixed aseptically after sterilizing the medium to give required concentrations viz., 1000, 1500, 2000, 2500 and 3000 ppm. For each concentration, copper hydroxide (Kocide 3000) was taken into a 100 $\mathrm{ml}$ Erlenmeyer flask containing $100 \mathrm{ml}$ of the sterilized and molten medium, mixed thoroughly by gently swirling the flask, poured $15 \mathrm{ml}$ in each sterile Petridish and allowed to solidify. A nine $\mathrm{mm}$ actively growing PDA culture disc of test fungus was placed at the centre of the plate and the plates were incubated in inverted position at room temperature $\left(28 \pm 2{ }^{\circ} \mathrm{C}\right)$. The PDA medium without copper hydroxide (Kocide 3000) and inoculated with $T$. viride served as control. Three replications were maintained for each concentration. The radial growth of mycelium was measured periodically at 1,2, 3, 4 and 5 days after inoculation.

\subsubsection{Statistical analysis}

The data generated from various experiments of this study were statistically analyzed by DMRT with IRRISTAT software. The data with per cent values were subjected to arc sine transformation.

\subsection{Bacterial biocontrol agents}

\section{Results}

The growth of bacteria (P. fluorescens and B. subtilis) in Copper hydroxide (Kocide 3000) amended broth was assessed by turbidomertic method and the results are presented in Tables 1 and 2. The bacterial growth was not affected by Copper hydroxide (Kocide 3000) even at the highest concentration of $500 \mathrm{ppm}$.

Table 1. Compatibility of Copper hydroxide (Kocide 3000) with Pseudomonas fluorescens

\begin{tabular}{|l|l|l|l|l|l|l|l|}
\hline \multirow{2}{*}{$\begin{array}{l}\text { Time } \\
\text { inoculation }\end{array}$} & $\mathbf{1 0 0}$ & $\mathbf{2 0 0}$ & $\mathbf{3 0 0}$ & $\mathbf{4 0 0}$ & $\mathbf{5 0 0}$ & Control & $\begin{array}{l}\text { Bacterial } \\
\text { control }\end{array}$ \\
\cline { 2 - 8 } & $1.49^{\mathrm{d}}$ & $1.42^{\mathrm{e}}$ & $1.32^{\mathrm{e}}$ & $1.40^{\mathrm{e}}$ & $0.87^{\mathrm{d}}$ & $0.07^{\mathrm{a}}$ & $1.82^{\mathrm{e}}$ \\
\hline 12 & $1.87^{\mathrm{c}}$ & $1.60^{\mathrm{d}}$ & $1.78^{\mathrm{d}}$ & $1.62^{\mathrm{d}}$ & $1.45^{\mathrm{c}}$ & $0.07^{\mathrm{a}}$ & $2.00^{\mathrm{d}}$ \\
\hline 18 & $2.09^{\mathrm{b}}$ & $1.92^{\mathrm{c}}$ & $2.00^{\mathrm{bc}}$ & $1.95^{\mathrm{c}}$ & $1.62^{\mathrm{c}}$ & $0.07^{\mathrm{a}}$ & $2.14^{\mathrm{cd}}$ \\
\hline 34 & $2.15^{\mathrm{ab}}$ & $2.10^{\mathrm{ab}}$ & $2.13^{\mathrm{ab}}$ & $2.00^{\mathrm{bc}}$ & $1.87^{\mathrm{b}}$ & $0.07^{\mathrm{a}}$ & $2.25^{\mathrm{bc}}$ \\
\hline 36 & $2.28^{\mathrm{a}}$ & $2.02^{\mathrm{abc}}$ & $2.23^{\mathrm{a}}$ & $2.13^{\mathrm{ab}}$ & $2.00^{\mathrm{ab}}$ & $0.07^{\mathrm{a}}$ & $2.40^{\mathrm{b}}$ \\
\hline 42 & $2.32^{\mathrm{a}}$ & $2.17^{\mathrm{a}}$ & $2.29^{\mathrm{a}}$ & $2.21^{\mathrm{a}}$ & $2.12^{\mathrm{a}}$ & $0.06^{\mathrm{a}}$ & $2.62^{\mathrm{a}}$ \\
\hline 48 & $2.00^{\mathrm{bc}}$ & $1.93^{\mathrm{bc}}$ & $1.92^{\mathrm{cd}}$ & $1.88^{\mathrm{c}}$ & $1.87^{\mathrm{a}}$ & $0.06^{\mathrm{a}}$ & $2.30^{\mathrm{bc}}$ \\
\hline
\end{tabular}

*Values are mean of three replications

In a column, means followed by a common letter are not significantly different at the 5\% level by DMRT

In P. fluorescens inoculated broth the turbidity increased with increase in incubation time ( 0.87 to 2.12$)$ in Copper hydroxide treated concentration of $500 \mathrm{ppm}$ while in control the turbidity did not increase $(0.07)$. When the incubation period was increased beyond 42 hours the turbidity was found to be decrease at all the concentrations.

In case of $B$. subtilis, the turbidity increased with increase in incubation time (0.62 to 1.25 ) in Copper hydroxide treated concentration of $500 \mathrm{ppm}$ while in control the turbidity did not increase (0.06). But the turbidity was found to decrease with incubation period of more than 42 hours at all the concentrations (Table 2.)

Table 2. Compatibility of Copper hydroxide (Kocide 3000) with Bacillus subtilis

\begin{tabular}{|c|c|c|c|c|c|c|c|}
\hline \multirow{2}{*}{$\begin{array}{l}\text { Time (hrs) } \\
\text { after } \\
\text { inoculation }\end{array}$} & \multicolumn{7}{|c|}{ Concentration (ppm) of Kocide/ OD value at $610 \mathrm{~nm} *$} \\
\hline & 100 & 200 & 300 & 400 & 500 & Control & $\begin{array}{c}\text { Bacterial } \\
\text { control }\end{array}$ \\
\hline 12 & $1.03^{\mathrm{e}}$ & $0.90^{\mathrm{d}}$ & $0.82^{\mathrm{c}}$ & $0.70^{\mathrm{d}}$ & $0.62^{\mathrm{e}}$ & $0.06^{\mathrm{a}}$ & $1.95^{\mathrm{e}}$ \\
\hline 18 & $1.43^{\mathrm{d}}$ & $0.98^{\mathrm{d}}$ & $0.95^{\mathrm{c}}$ & $0.84^{\mathrm{cd}}$ & $0.72^{\mathrm{de}}$ & $0.06^{\mathrm{a}}$ & $2.16^{\mathrm{d}}$ \\
\hline 24 & $1.67^{\mathrm{c}}$ & $1.05 \mathrm{~cd}$ & $0.98^{\mathrm{c}}$ & $0.97^{\mathrm{c}}$ & $0.85^{\mathrm{cd}}$ & $0.06^{\mathrm{a}}$ & $2.32^{\mathrm{d}}$ \\
\hline 30 & $1.77^{\mathrm{bc}}$ & $1.32^{\mathrm{c}}$ & $0.98^{c}$ & $0.97^{c}$ & $0.94^{\mathrm{bc}}$ & $0.06^{\mathrm{a}}$ & $2.53^{c}$ \\
\hline 36 & $1.95^{\mathrm{a}}$ & $1.72^{b}$ & $1.32^{b}$ & $1.22^{b}$ & $1.18^{\mathrm{ab}}$ & $0.06^{\mathrm{a}}$ & $2.89^{b}$ \\
\hline 42 & $2.02^{\mathrm{a}}$ & $1.96^{\mathrm{a}}$ & $1.51^{\mathrm{a}}$ & $1.42^{\mathrm{a}}$ & $1.25^{\mathrm{a}}$ & $0.06^{\mathrm{a}}$ & $3.12^{\mathrm{ab}}$ \\
\hline 48 & $1.90^{\mathrm{ab}}$ & $1.80^{\mathrm{ab}}$ & $1.40^{\mathrm{a}}$ & $1.30^{\mathrm{ab}}$ & $1.10^{\mathrm{ab}}$ & $0.06^{\mathrm{a}}$ & $3.10^{\mathrm{a}}$ \\
\hline
\end{tabular}

*Values are mean of three replications 

DMRT

In a column, means followed by a common letter are not significantly different at the $5 \%$ level by

\subsection{Fungal biocontrol agent}

Copper hydroxide (Kocide 3000) at 100 through 500 ppm concentration did not increase the growth of the mycelium of Trichoderma viride under in-vitro condition, hence a higher dosage of 1000 to $3000 \mathrm{ppm}$ was used to test compatibility with $T$. viride. The concentration of 1000 and $1500 \mathrm{ppm}$ was not inhibitory with 7.50 and $6.83 \mathrm{~cm}$ of mycelial growth in 5 days as against $9.00 \mathrm{~cm}$ in control. A significant difference in mycelial growth of $T$. viride was observed in concentration from $2000 \mathrm{ppm}$ to $3000 \mathrm{ppm}$ when compared to control [Plate 1; Table 3].

Table 3. Mycelial growth of Trichoderma viride amended with Copper hydroxide (Kocide 3000)

\begin{tabular}{|c|c|c|c|c|c|c|}
\hline \multirow{2}{*}{$\begin{array}{c}\text { Days after } \\
\text { inoculation }\end{array}$} & \multicolumn{5}{|c|}{ Concentration (ppm) of Kocide/ diameter of mycelial growth (cm) * } \\
\cline { 2 - 7 } & $\mathbf{1 0 0 0}$ & $\mathbf{1 5 0 0}$ & $\mathbf{2 0 0 0}$ & $\mathbf{2 5 0 0}$ & $\mathbf{3 0 0 0}$ & Control \\
\hline 1 & $1.57^{\mathrm{e}}$ & $1.20^{\mathrm{e}}$ & $0.60^{\mathrm{e}}$ & $0.50^{\mathrm{e}}$ & $0.40^{\mathrm{e}}$ & $2.30^{\mathrm{d}}$ \\
\hline 2 & $3.20^{\mathrm{d}}$ & $2.50^{\mathrm{d}}$ & $1.70^{\mathrm{d}}$ & $1.40^{\mathrm{d}}$ & $1.00^{\mathrm{d}}$ & $3.70^{\mathrm{c}}$ \\
\hline 3 & $5.60^{\mathrm{c}}$ & $4.10^{\mathrm{c}}$ & $3.50^{\mathrm{c}}$ & $2.60^{\mathrm{c}}$ & $2.10^{\mathrm{c}}$ & $7.80^{\mathrm{b}}$ \\
\hline 4 & $7.20^{\mathrm{b}}$ & $5.60^{\mathrm{b}}$ & $3.90^{\mathrm{b}}$ & $3.80^{\mathrm{b}}$ & $2.80^{\mathrm{b}}$ & $9.00^{\mathrm{a}}$ \\
\hline 5 & $7.50^{\mathrm{a}}$ & $6.83^{\mathrm{a}}$ & $4.30^{\mathrm{a}}$ & $4.20^{\mathrm{a}}$ & $3.00^{\mathrm{a}}$ & $9.00^{\mathrm{a}}$ \\
\hline
\end{tabular}

*Values are mean of three replications DMRT

In a column, means followed by a common letter are not significantly different at the $5 \%$ level by

Fig. 1 Mycelial growth of Trichoderma viride amended with Copper hydroxide (Kocide 3000)

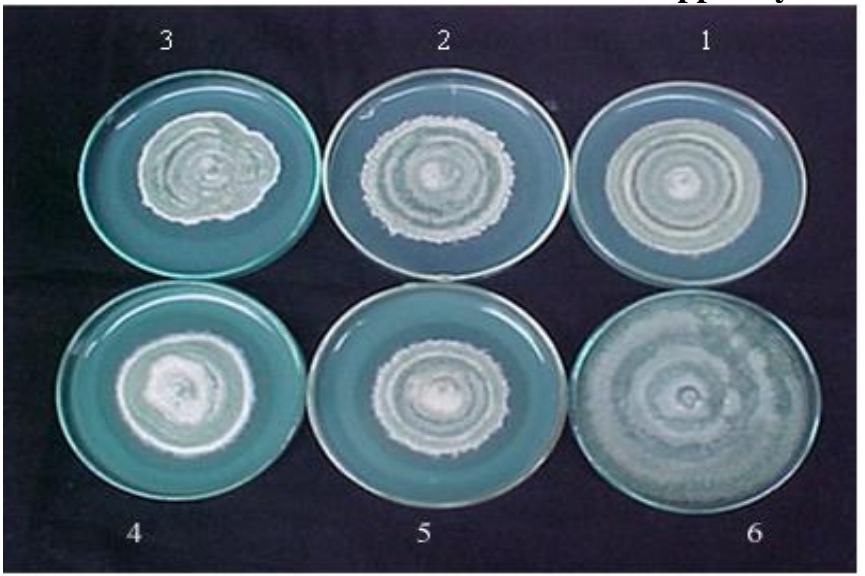

\begin{tabular}{|ll|ll|}
\hline 1. & $1000 \mathrm{ppm}$ & 2. & $2500 \mathrm{ppm}$ \\
\hline 2. & $1500 \mathrm{ppm}$ & 3. & $3000 \mathrm{ppm}$ \\
\hline 3. & $2000 \mathrm{ppm}$ & 4. & Control \\
\hline
\end{tabular}

\section{Discussion}

Fungicides that are active against a narrow spectrum of plant pathogens but not against biocontrol agents afford an opportunity for the integration of chemical with biological agents. Knowledge of compatibility of biocontrol agents with other components of the production system is needed to develop feasible management strategies. There are very few reports about the compatibility of copper fungicides with the biocontrol agents.

Our findings are in similar with the studies by using Copper oxychloride, mancozeb, fosetyl-Al and cymoxanil $8 \%$ + mancozeb $64 \%$ mixture fungicides showed moderate to good compatibility with $T$. viridel by exhibiting tolerance limits $\left(\mathrm{ED}_{50}\right)$ of 848, 710, 578 and $448 \mu \mathrm{g} / \mathrm{ml}$ respectively (Gaur and Sharma, 2010) [11].

Many reports showed compatibility of biocontrol agents with systemic fungicides like azoxystrobin. Kataria et al. (2002) [12] reported that lower rates of azoxystrobin applied as seed treatment in combination with $P$. fluorescens. strain W36 showed better antagonist interaction against Rhizoctonia solani Kuhn. in bean and cucumber. Sendhilvel et al. (2004) [6] found that P. fluorescens and B. subtilis (Ehrenberg) Cohn. growth was not affected by azoxystrobin at different concentrations of 100, 150, 200, 250 and 300 ppm. Similarly, Anand et al. (2007) [7] also reported the compatibility of P. fluorescens (Pf1) and B. subtilis with azoxystrobin. Copper oxychloride was found as highly compatible with T. harzanium (Susheela and Thomas, 2010) [13]. 
From the above study, it was concluded that apart from effective management of bacterial and fungal diseases by copper hydroxide (Kocide 3000), the compatibility with bacterial and fungal bio control agents enhances wider opportunity in the agro ecosystem with minimal residual effect.

\section{Acknowledgement}

The authors like to thank the E.I. DuPont India Private Limited, India for the financial support which enabled carrying out this research.

\section{References}

[1]. http://www.dupont.com/ProductionAgriculture/en_US/products_services/fungicides/Kocide3000_fungicide.html - 25k.

[2]. G C Papaviza and J.A. Lewis, Introduction and augmentation of microbial antagonists for the control of soil borne plant pathogens, in G.C. Papavizas (Ed.), Biological Control in Crop Production, (New York Allanheld, Osmum 1981) 305-322

[3]. S J Kay and A.Stewart. The effect of fungicides on fungal antagonists of onion white rot and selection of dicarboximide-resistant biotypes. Plant Pathology, 43, 1994, 863-871.

[4]. Z Naar and M. Keeskes. Antagonism of Trichoderma atroviride and Trichoderma viride strains against Sclerotinia minor as influenced by mancozeb, benomyl and vinclozolin. Acta Phytopathologica Et Entomologica Hungarica, 33, 1998, $123-130$.

[5]. R S Utkhede and C.A. Koch, Chemical and biological treatments for control of gummy stem blight of greenhouse cucmber European journal of Plant Pathology, 108, 2002, 443-448.

[6]. V. Sendhilvel, T. Marimuthu and T. Raguchander, Compatibility of azoxystrobin 25 SC with biocontrol agents. Pestology, 28, 2004, 61-64.

[7]. T Anand, V. Prakasam, A. Chandrasekaran, R. Samiyappan, G. Karthikeyan, and A. Saravanan, Compatibility of azoxystrobin (Amistar 25 SC) with biocontrol agents. Pestology, 31, 2007, 21-24.

[8]. R Rodriguez - Kabana, and E.A. Curl, Non target effect of pesticides on soil borne pathogens and disease. Annual Review of Phytopathology, 17, 1980, $311-312$.

[9]. R S Singh, A. Jindal, D. Singh and T. Singh, Selection of Trichoderma isolates against common fungicides for their use in Integrated Plant Disease Management, in Special issue of the Global conference on Advances in Research on plant disease and their management, (Udaipur, Rajasthan 1995) 127-128.

[10]. S C Dubey, Biological management of web blight of groundnut (Rhizoctonia solani), Journal of Mycology and Plant Pathology, 30, 2000, 89-90.

[11]. R B Gaur, R N. Sharma, Biocontrol of Root Rot in Cotton and Compatibility of Potential Bioagents with Fungicides, Indian Journal of plant protection, 38 (2), 2010, 176-182

[12]. H R Kataria, B. Wilmsmeier, and H. Buchenauer. Efficacy of Pseudomanas fluorescens strains and some modern fungicides for control of Rhizoctonia solani AG-4 in bean and cucumber. Journal of Plant Disease and Protection, 109, 2002, 384-400.

[13]. B. Suseela and J. Thomas, Compatibility of Trichoderma harzianum (Ritai.) with fungicides, insecticides and fertilizers. Indian Phytopathology, 63 (2), 2010, 145-148 